\title{
Prediction of duration of breast feeding in primiparas
}

\author{
H J WRIGHT AND P C WALKER
}

From the Department of Community Medicine and General Practice, University of Leeds, Leeds, UK

SUMMARY A random sample of 617 primiparas was identified from birth notifications over a 12 month period and 534 of these were interviewed four weeks after confinement. Those breast feeding at the time of interview were contacted again at four months and those still breast feeding then were contacted at six and a half months. Duration of breast feeding was found to be significantly associated with five interassociated personal characteristics of the mother and with specific aspects of her knowledge and attitudes regarding breast feeding. In hospital the timing of the first breast feed and difficulties with subsequent feeds, were important indicators; while at home the use of additional formula feeds was associated with a reduced prevalence of breast feeding by 18 weeks. A combination of older maternal age at confinement and older age at leaving school showed a tenfold increase of prevalence rates in breast feeding at 16 weeks between groups of mothers. The use of these two factors alone may thus help doctors, midwives, and health visitors in assessing the risk of premature termination of breast feeding and in planning programmes of preventive care.

\begin{abstract}
"The working party are convinced that when successfully managed breast feeding of four to six months' duration effectively safeguards the infant from the adverse conditions associated with artificial feeding."1
\end{abstract}

Since the publication of Howarth's paper in $1905,{ }^{2}$ the biological advantages of breast feeding have been widely documented. ${ }^{3}$ While there is evidence, however, that the incidence of attempted breast feeding has been increasing in Britain over the past 20 years, many mothers continue breast feeding for brief periods only..$^{-6}$ Measures designed to maintain it for longer periods are thus important.

With increasingly early discharge from hospital care, such measure are largely the responsibility of general practitioners, midwives, and health visitors, and, as in other forms of preventive care, their efficiency depends on the ability to identify beforehand those groups of mothers at particular risk. The present report is concerned with such prediction.

\section{Methods}

Over a period of 12 months a random sample of 617 primiparae was drawn from first births notified to the Leeds Area Health Authority, ${ }^{3}$ and a letter was sent to each mother requesting an opportunity to discuss the care of her child with her at home.
Mothers were interviewed as close to four weeks after confinement as possible. Using a standardised interview schedule, questions were asked regarding personal characteristics; events during pregnancy, confinement, and puerperium; mothers' experiences in infant feeding; and the social and attitudinal environment in which it occurred.

To establish the duration of breast feeding, those still doing so at interview were sent a brief postal questionnaire when their child was 4 months old. Those mothers still breast feeding then were sent a further similar questionnaire at $6 \frac{1}{2}$ months.

In reporting the findings the term "weaning" has, because of its ambiguity, ${ }^{7}$ been avoided; and "duration of breast feeding" means the period for which a mother reported her child as having been breast fed at all, irrespective of the concomitant use of other foods. From the data collected the periods during which mothers ceased breast feeding were determined, and the Chi-squared test was then used to determine the significance of differences observed in contingency tables analysing these periods.

\section{Results}

Of 617 mothers in the selected sample, 534 (87\%) were interviewed. The 83 mothers who were not interviewed showed some overrepresentation of social classes IV and V but no significant differences in respect of maternal age or babies' birth weights. Of 
Table 1 Factors significantly associated with the duration of breast feeding in 373 primiparas

\begin{tabular}{|c|c|}
\hline Factors significantly associated $(p<0.05)$ & Factors not significantly associated $(p<0.05)$ \\
\hline $\begin{array}{l}\text { Personal characteristics of mother: } \\
\text { Age at birth of child } \\
\text { Social class } \\
\text { Age at leaving school } \\
\text { Smoking habits } \\
\text { Mother's own infant feeding history } \\
\text { Antenatal events } \\
\text { Attendance at mothercraft classes } \\
\text { Education in specific aspects of infant feeding } \\
\text { Antenatal preparation of breasts }\end{array}$ & $\begin{array}{l}\text { Stage at which pregnancy confirmed } \\
\text { No of antenatal attendances } \\
\text { Antenatal period in hospital } \\
\text { Perceived normality of pregnancy } \\
\text { Perceived favourability of medical advisers' views } \\
\text { during pregnancy to breast feeding }\end{array}$ \\
\hline $\begin{array}{l}\text { Events surrounding birth } \\
\text { None }\end{array}$ & $\begin{array}{l}\text { Mode of delivery: perceived normality: } \\
\text { level of consciousness: favourability of } \\
\text { mother's feelings about her confinement } \\
\text { Father's presence during labour/birth } \\
\text { Baby's sex: birth weight: perceived normality at birth: } \\
\text { admission to special care }\end{array}$ \\
\hline $\begin{array}{l}\text { Puerperal period in hospital } \\
\text { Time of first breast feeding } \\
\text { Difficulties at subsequent breast feeds in hospital } \\
\text { Perceived favourability of medical advisers' views } \\
\text { during puerperium to breast feeding }\end{array}$ & $\begin{array}{l}\text { Favourability of mother's feelings } \\
\text { at first seeing her child } \\
\text { Maternal-child contact } \\
\text { Feeding routines } \\
\text { Difficulties at first breast feed } \\
\text { Privacy, and mother's response to it } \\
\text { Duration of hospital stay }\end{array}$ \\
\hline $\begin{array}{l}\text { First four weeks at home } \\
\text { Use of additional feeds } \\
\text { Perceived views of friends with young babies } \\
\text { Maternal attitudes to breast feeding }\end{array}$ & $\begin{array}{l}\text { Feeding routines-fixed interval or "demand": } \\
\text { frequency of feeding } \\
\text { Perceived views of husband, maternal grandmother, } \\
\text { and other relatives on infant feeding }\end{array}$ \\
\hline
\end{tabular}

the 534 mothers interviewed, $373(69 \cdot 9 \%)$ attempted breast feeding. Figure 1 shows the proportions of these still breast feeding at weekly intervals thereafter. Table 1 summarises the factors significantly associated or not with duration of breast feeding.

\section{PERSONAL CHARACTERISTICS OF MOTHER Maternal age at child's birth}

Differences between younger and older mothers were significant by six weeks and remained so thereafter. Comparable findings have been reported elsewhere. ${ }^{689}$

\section{Social class}

By eight weeks postpartum, mothers in social classes I and II were significantly more likely to be breast feeding than mothers in social classes IV and V and, by 18 weeks, than mothers in social class III(nm). Mothers in social class III(m) showed no significant differences from those in social classes IV and V. Many studies have reported similar social class associations. $^{6}$ 10-12
Table 2 Period at which breast feeding was stopped: by age of mother at birth of child $(n=373)$

\begin{tabular}{|c|c|c|c|c|c|c|}
\hline $\begin{array}{l}\text { Age of } \\
\text { mother } \\
\text { (years) }\end{array}$ & $\begin{array}{l}\text { No } \\
\text { of } \\
\text { mothers }\end{array}$ & $\begin{array}{l}\text { Perce } \\
0-2 \\
w k s\end{array}$ & $\begin{array}{c}\text { gge wh } \\
3-4 \\
\text { wks }\end{array}$ & $\begin{array}{l}\text { stopped } \\
5-16 \\
\text { wks }\end{array}$ & $\begin{array}{l}\text { reast feed } \\
17-26 \\
w k s\end{array}$ & $\begin{array}{l}\text { ing at } \\
\geqslant 27 \\
\text { wks }\end{array}$ \\
\hline $\begin{array}{l}<20 \\
20-24 \\
25-29 \\
\geqslant 30\end{array}$ & $\begin{array}{r}56 \\
149 \\
120 \\
48\end{array}$ & $\begin{array}{l}43 \\
34 \\
21 \\
17\end{array}$ & $\begin{array}{l}25 \\
15 \\
12 \\
17\end{array}$ & $\begin{array}{l}27 \\
29 \\
18 \\
27\end{array}$ & $\begin{array}{l}1 \\
7 \\
9 \\
8\end{array}$ & $\begin{array}{r}4 \\
15 \\
40 \\
31\end{array}$ \\
\hline
\end{tabular}

Age at leaving school: educational attainment

The older the mother's age at leaving school, or the higher her educational attainment, the longer she was likely to breast feed; differences between groups being significant by four weeks after birth (table 3 ). Other papers have reported similar findings, ${ }^{68913}$ but the validity of these has been questioned. ${ }^{14} 15$

\section{Smoking habits}

Prevalence rates declined more steeply among mothers who smoked (habitually or occasionally) than among those who did not, and by the eighteenth week differences were significant $(p<0 \cdot 05) .{ }^{16} 17$ 


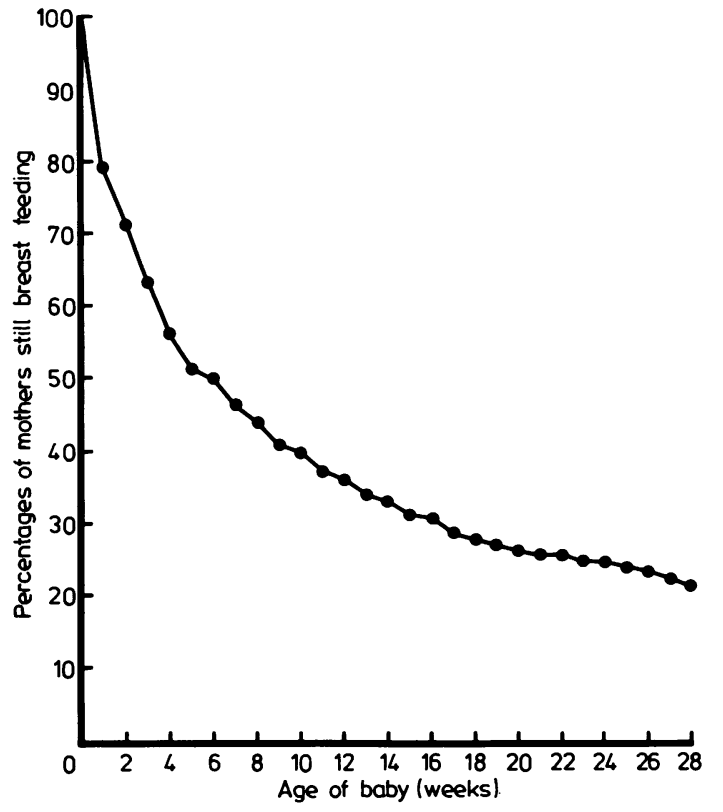

Fig 1 Percentages of 373 mothers still breast feeding at weekly intervals after birth.

\section{Other factors}

In contrast, no significant associations were found between duration of breast feeding and the mother's employment status during pregnancy, intention to return to work, or medical history.

As regards marital status, the rate of decline during the first six weeks was noticeably but not statistically significantly greater among single than among married mothers and greater among single mothers not cohabiting than those cohabiting. 9

\section{EVENTS DURING PREGNANCY}

\section{Attendance at mothercraft classes}

Prevalence rates of breast feeding were significantly greater (from the fourth week postpartum) among mothers who had attended mothercraft classes than among those who had not.

Table 3 Period at which breast feeding was stopped: by age of mother at leaving school $(n=373)$

\begin{tabular}{lllllll}
\hline $\begin{array}{l}\text { Age at } \\
\text { leaving }\end{array}$ & $\begin{array}{l}\text { No } \\
\text { of }\end{array}$ & \multicolumn{6}{c}{ Percentage who stopped breast feeding at } \\
school & mothers & $\begin{array}{l}0-2 \\
\text { wks }\end{array}$ & $\begin{array}{c}3-4 \\
\text {.wks }\end{array}$ & $\begin{array}{l}5-16 \\
\text { wks }\end{array}$ & $\begin{array}{l}17-26 \\
\text { wks }\end{array}$ & $\begin{array}{l}\geqslant 27 \\
\text { wks }\end{array}$ \\
\hline$<16$ & 101 & 41 & 17 & 20 & 9 & 13 \\
16 & 164 & 34 & 16 & 28 & 7 & 15 \\
17 & 26 & 4 & 15 & 42 & 4 & 35 \\
$\geqslant 18$ & 82 & 11 & 12 & 20 & 7 & 50 \\
\hline
\end{tabular}

"Additionally, two breast feeding mothers had been confined at home.
Mothers' education in specified aspects of breast feeding

Mothers who recalled having had information regarding any of five specified aspects of breast feeding (antenatal preparation of breasts, care of nipples, expression of surplus milk, need for extra fluids, and management of painful breasts) showed significantly higher prevalence rates of breast feeding from six weeks onwards than those who did not (table 4).

Table 4 Period at which breast feeding was stopped, by mother's information regarding specified aspects: "What to do about painful breasts" $(n=373)$

\begin{tabular}{|c|c|c|c|c|c|c|}
\hline $\begin{array}{l}\text { Mother } \\
\text { recalls } \\
\text { information } \\
\text { from }\end{array}$ & $\begin{array}{l}\text { No } \\
\text { of } \\
\text { mothers }\end{array}$ & $\begin{array}{l}\text { Perc } \\
0-2 \\
\text { wks }\end{array}$ & $\begin{array}{c}\text { ige wh } \\
3-4 \\
w k s\end{array}$ & $\begin{array}{l}\text { topped } \\
5-16 \\
w k s\end{array}$ & $\begin{array}{l}\text { reast feed } \\
17-26 \\
w k s\end{array}$ & $\begin{array}{l}\text { ing at } \\
\geqslant 27 \\
\text { wks }\end{array}$ \\
\hline $\begin{array}{l}\text { At least one } \\
\text { source } \\
\text { No source }\end{array}$ & $\begin{array}{l}214 \\
159\end{array}$ & $\begin{array}{l}19 \\
41\end{array}$ & $\begin{array}{l}20 \\
24\end{array}$ & $\begin{array}{l}23 \\
19\end{array}$ & $\begin{array}{l}5 \\
3\end{array}$ & $\begin{array}{l}32 \\
13\end{array}$ \\
\hline
\end{tabular}

Antenatal preparation of breasts

Significantly higher prevalence rates (from the eighth week onwards) were found among $\mathbf{2 1 2}$ mothers who had systematically taken steps during pregnancy to prepare their breasts than among those who had not.

\section{Other factors}

No significant differences in duration were found associated with the stage at which pregnancy was medically confirmed; the number of antenatal days spent in hospital, the perceived normality of pregnancy, or mothers' perceptions of their medical advisers' views on infant feeding.

\section{EVENTS SURROUNDING THE BIRTH}

No significant associations were found between the prevalence rates of breast feeding and the mode of delivery; the mother's feelings about her confinement; her perceptions of its normality or of her level of consciousness at delivery, and the child's sex; his normality as perceived by the mother; or his admission to, or duration in, special care.

Although prevalence rates were consistently higher when the father was present at the birth, the child's birth weight was $2500 \mathrm{~g}$ or more, or the mother stayed not more than two days in hospital than where the reverse obtained, the differences were not statistically significant.

PUERPERAL PERIOD IN HOSPITAL

Of the $371^{*}$ mothers who attempted to breast feed in hospital, $78(21 \%)$ stopped before discharge and of 156 breast feeders who stayed in hospital for seven days or under, $74(47 \%)$ had ceased breast feeding on discharge. 
The early decline in prevalence is thus considerable, and management during this period needs critical attention.

\section{Feeding routines}

Among mothers who had first breast fed within 12 hours, prevalence rates were significantly higher ( $p<0.01$ at eight weeks: $p<0.05$ thereafter) than among those who started breast feeding later, and were consistently higher among mothers who breast fed within one hour of birth. ${ }^{18} 19$ This association, however, is not necessarily a simple one, since the timing of the first feed was also found to be significantly associated with the mother's educational attainment and social class. As table 1 shows, no significant associations were found between the subsequent duration of breast feeding and the type of schedule adopted, the frequency of breast feeding in the first three days, the use of additional formula feeds, or expression of the breasts after feeding. ${ }^{21}$

\section{Early feeding difficulties}

Except in the case of the child's first feed, mothers who recalled difficulties with breast feeding while in hospital were significantly more likely than other mothers to cease breast feeding within two weeks.

\section{Maternal-child contact}

In contrast to other reports, ${ }^{18}$ no significant differences in subsequent duration of breast feeding were found between mothers who had, and those who had not, held their baby immediately after birth. Prevalence rates up to 26 weeks were consistently (but not significantly) higher among mothers who had had their child with them all the time than among those with whom the child spent daytime only and both were higher than when some more restricted arrangement applied..$^{22}$

\section{Views of hospital medical staff}

The duration of subsequent breast feeding was significantly longer among mothers who during their time in hospital perceived their medical advisers as favouring breast feeding than among mothers who believed their advisers' views to have been neutral or unfavourable $(\mathrm{p}<0.05)$.

\section{Privacy}

No significant differences in the duration of breast feeding were observed between mothers who were/were not accommodated in single rooms, were/were not screened off during feeding, or who objected to/accepted these arrangements.

\section{BREAST FEEDING AT HOME}

The early weeks at home are, likewise, a period of rapid decline in the prevalence of breast feeding. Of 293 mothers who were breast feeding when discharged from hospital, only 199 were still doing so at the interview four weeks later.

\section{Feeding routines and use of additional formula-feeding}

Conflicting views have been expressed on the use of complementary and supplementary feeds. ${ }^{24}{ }^{25}$ Of the 293 mothers, $122(42 \%)$ said at interview that they had used additional bottle feeding at home: the prevalence rates of breast feeding among these were, by the 18 th week, significantly lower than among those who had not.

\section{Interpersonal environment}

The prevalence of breast feeding (from the fourth week onwards) among mothers who perceived their friends with young babies as being generally in favour of breast feeding was significantly greater than among those who thought their friends to be generally in favour of bottle feeding. ${ }^{12}$ No such associations, however, were found related to the views of husband, maternal grandmother, or other relatives and friends.

Mothers' attitudes and reactions to breast feeding The influence of mothers' attitudes on the incidence and duration has been widely discussed. ${ }^{26-30}$ In the present study mothers were asked at the end of interview to respond ("agree," "not sure," "disagree") to 17 statements about infant feeding.

Convenience-Breast feeding mothers who agreed with the view that "bottle feeding is more convenient" were significantly less likely to continue breast feeding after the fourth week than those who disagreed.

Uncertainty-Similar findings were evident among those who agreed that "it is a disadvantage of breast feeding that you do not know if the baby has had enough milk."

Embarrassment-Prevalence rates from four weeks onwards were significantly lower among mothers who said they would be (were) embarrassed by breast feeding at home in front of their mother, a female friend, or a friend's husband than among those who were not embarrassed. A similar finding was evident among breast feeding mothers who agreed with the statement "you can bottle feed anywhere but you have to breast feed at home."

Enjoyment-The subsequent prevalence rates 
among mothers who, at interview, said that they enjoyed breast feeding "a lot" were consistently higher than those who "quite liked it"; both were significantly greater than mothers who enjoyed it "not at all."

\section{Discussion}

The importance of the mothers' personal and attitudinal characteristics in relation to the duration of breast feeding is implicit in table 1 . Nevertheless, characteristics that are to be used predictively to identify groups of mothers at high risk of terminating breast feeding prematurely need to be easily and reliably identifiable, stable, and determinable before confinement. Since these criteria are often difficult to meet in respect of attitudes, values, and perceptions, analysis initially examined the predictive capacity of other more reliably determinable personal characteristics (mother's age group, age at leaving school, social class, marital state, and smoking habits).

These five characteristics proved to be significantly interrelated in the study group (table 5). When the predictive effectiveness of these characteristics, singly and in various pairs, was examined graphically the combination of age group of mother (under 20, $20-24,25$ or over) with age on leaving school (16 or under; 17 or over) provided the best separation of prevalence rates. between groups of mothers, with differences between groups being evident within a few weeks of birth (fig 2).

At six weeks postpartum mothers who were aged 25 or over and who had left school at 17 were four times more likely to be still breast feeding than were mothers aged under 20 who had left school at 16 ; and by 16 weeks postpartum this ratio has become 10 to one.

Although the effect of incorporating a third factor could not in this study be confidently judged, since doing so produced several categories too small for assessment, it did not appear to improve predictive effectiveness appreciably.

Table 5 Interassociations $(p<0.01)$ of personal factors associated with duration of breast feeding

\begin{tabular}{llllll}
\hline & $\begin{array}{l}\text { Maternal } \\
\text { age at } \\
\text { birth/child }\end{array}$ & $\begin{array}{l}\text { Age at } \\
\text { leaving } \\
\text { school }\end{array}$ & $\begin{array}{l}\text { Social } \\
\text { class }\end{array}$ & $\begin{array}{l}\text { Marital } \\
\text { state }\end{array}$ & $\begin{array}{l}\text { Smoking } \\
\text { habits }\end{array}$ \\
\hline $\begin{array}{l}\text { Maternal age } \\
\text { (at birth/child) }\end{array}$ & & & & \\
$\begin{array}{l}\text { Age at } \\
\text { leaving school }\end{array}$ & + & & & \\
$\begin{array}{l}\text { Social class } \\
\text { Marital state }\end{array}$ & + & + & & \\
$\begin{array}{l}\text { Smoking habits } \\
+\end{array}$ & + & + & + & + \\
\hline
\end{tabular}

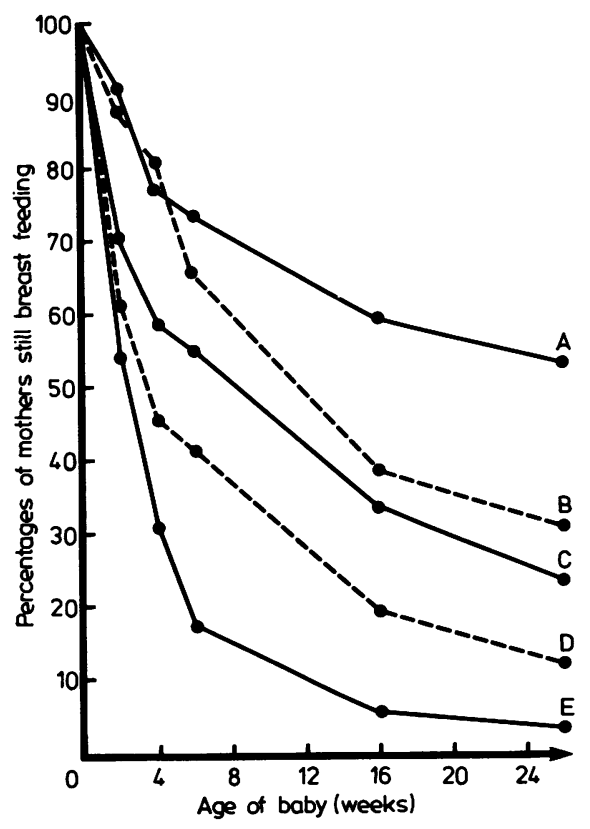

Fig 2 Percentages of mothers still breast feeding at difference stages by age of mother at confinement and age at leaving school. A Aged 25 or over: left school at 17 or over $(n=79) ; B$ aged 20-24: left school at 17 or over $(n=26)$; $C$ Aged 25 or over: left school at 15 or $16(n=89) ; D$ Aged 20-24: left school at 15 or $16(n=123)$; $E$ aged under 20 : left school at 15 or $16(n=53)$. (Only three mothers aged under 20 who left school at 17 or over attempted breast feeding.)

\section{ENVIRONMENTAL FACTORS}

Table 1 also identifies the environmental factors during pregnancy, birth, and puerperium associated with premature termination of breast feeding. Compared with the overall number of factors examined they are remarkably few and implicitly appear to relate more to personal qualities of care than to its organisation or technology. Nevertheless, where these environmental factors are known to have operated adversely they may heighten the risks of early termination inherent in the mother's personal characteristics.

\section{ATTITUDINAL FACTORS}

Mothers' attitudes to breast feeding were expressed some four weeks after the birth of their child. Their influence on the rapid decline of breast feeding in the early postnatal period cannot, therefore, be reliably assessed. Nevertheless, attitudes expressed towards the convenience, uncertainty, embarrassment, and enjoyment of breast feeding clearly relate to its 
subsequent duration; and the doctor may usefully use them in considering the likelihood of a mother terminating breast feeding prematurely.

If breast feeding for some four months is to become the socially accepted norm, the support of mothers who start to breast feed is evidently as important as efforts to increase its incidence. The ability to identify, and focus support, groups of mothers at particular risk of premature termination is thus important.

To define such high risk groups a wide variety of factors must be considered and their interassociations examined. The findings of the present study suggest that premature termination is principally predicated by personal characteristics of the mother and is conditioned by her knowledge of, and affective responses to, breast feeding. Young mothers who have left school early are at greatest risk, and the principal danger period is the first four to six weeks postpartum.

The view has been expressed that present obstetrical methods may severely inhibit the level of breast feeding. ${ }^{31}$ Little evidence was found to support this: indeed their lack of impact on the duration of breast feeding was striking.

We thank Professor I D G Richards for permission to publish this paper and the Yorkshire Regional Health Authority for funding the study. Copies of the interview questionnaire and further statistical data may be had from Dr $\mathrm{H} \mathrm{J}$ Wright on request.

\section{References}

${ }^{1}$ Department of Health and Social Security. Present-day practice in infant feeding. Report on health and social subjects No 9. London: HMSO, 1974.

${ }^{2}$ Howarth WJ. The influence of feeding on the mortality of infants. Lancet 1905; ii: 210-3.

${ }^{3}$ Wright HJ, Walker PC, Webster J. The prediction of choice in infant feeding. $J \boldsymbol{R}$ Coll Gen Pract (in press).

4Arneil GC. Dietary study of 4365 Scottish infants-1965. Scottish health service studies No 6. Edinburgh: HMSO, 1967.

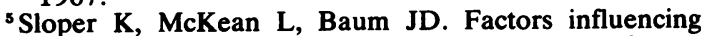
breast feeding. Arch Dis Child 1975; 50: 165-70.

${ }^{6}$ Martin J. Infant feeding 1975: attitudes and practice in England and Wales. London: HMSO, 1978.

${ }^{7}$ Morley DC. Paediatric priorities in the developing world. London: Butterworths, 1974.

${ }^{8}$ Prothero R. Women who still breastfeed their babies. Medical Officer 1969 March 14: 141-2.
${ }^{9}$ Sjolin S, Hofvander Y, Hillervick C. Factors related to early termination of breastfeeding. Acta Paediatr Scand 1977; 66: 505-11.

${ }^{10}$ Douglas JWB. The extent of breastfeeding in Great Britain in 1946, with special reference to the health and survival of children. Journal of Obstetrics and Gynaecology of the British Empire 1950; 57: 335-61.

${ }^{11}$ Newson J, Newson E. Patterns of infant care in an urban community. Harmondsworth: Penguin Books Limited, 1965.

12 Jones RAK, Belsey EM. Breastfeeding in an inner London borough-a study of cultural factors. Soc Sci Med 1977; 11: 175-9.

${ }^{13}$ Pursall EW, Jepson ME, Smith BAM, Emery JL. Breastfeeding and mothers' education. Lancet 1978; ii: 734-5.

${ }^{14}$ Kirk TR. Breastfeeding and mothers' education. Lancet 1978; ii: 1201-2.

${ }^{15}$ Last P. Breastfeeding and mothers' education. Lancet 1978; ii: 896-7.

${ }^{16}$ Whichelow MJ, King BE. Breastfeeding and smoking. Arch Dis Child 1979; 54: 240-1.

${ }^{17}$ Meyer MB. Breastfeeding and smoking. Lancet 1979; i: 975-6.

${ }^{18} \mathrm{de}$ Chateau $P$, Winberg $L$. Immediate postpartum suckling contact and duration of breastfeeding. Journal of Maternal and Child Health 1978: 3: 392-5.

${ }^{19}$ Salariya EM, Easton PM, Cater JI. Duration of breastfeeding after early initiation and frequent feeding. Lancet 1978; ii: 1141-3.

${ }^{20}$ Blackley J, Clarke S, MacKeith R, Ogden KM. Breastfeeding: factors affecting success. Journal of Obstetrics and Gynaecology 1952; 60: 657-69.

${ }^{21}$ Sosa R, Kennell JH, Klaus M, Urrutia JJ. The effect of early mother-infant contact on breastfeeding, infection and growth. Amsterdam: Elsevier, 1976: 179-91. (Ciba Foundation Symposiưm No 45.)

${ }^{22}$ Jackson EB, Wilkin LC, Auerback H. Statistical report on incidence and duration of breastfeeding in relation to personal-social factors and hospital maternity factors. Pediatrics 1956; 17: 700-13.

${ }^{23}$ Anonymous. Mothering the baby. Br Med J 1972; ii: 419-20.

${ }^{24}$ Culley P, Milan P, Rogniski C, Waterhouse J, Wood B Are breast-fed babies still getting a raw deal in hospital? Br Med J 1979; ii: 891-2.

${ }^{25}$ Davies DP, Thomas C. Why women stop breastfeeding. Lancet 1976; i: 420-1.

${ }^{28}$ Potter HW, Klein HR. On nursing behaviour. Psychiatry 1957; 20: 39-46.

${ }^{27}$ Newton N, Newton M. Psychologic aspects of lactation. $N$ Eng J Med 1967; 227: 1179-90.

${ }^{28}$ Freedman GR. Breastfeeding - a year's experience of one group practice. J $R$ Coll Gen Pract 1976; 26: 507-13.

${ }^{29}$ Bacon CJ, Wylie JM, Mothers' attitudes to infant feeding at Newcastle General Hospital in summer 1975. Br Med $J$ 1976; i: 308-9.

${ }^{30}$ Call JD. Emotional factors favouring successfu breastfeeding of infants. J Pediatr 1959; 54: 485-96.

31 Jelliffe DB, Jelliffe EPP. Human milk in the modern world. Oxford: Oxford University Press, 1978: 193. 